\title{
Current Status of Faculty Development Events in Different Medical Institutions of Bangladesh
}

\author{
Wakil Ahmed ${ }^{1}$, Zinat Rehana Shipu ${ }^{2}$, Syed Zakir Hossain ${ }^{3}$, Syeda Afroza ${ }^{4}$. Md. Humayun \\ Kabir Talukder ${ }^{4}$
}

\begin{abstract}
Objective: To assess the current status of faculty development events in different Medical institutions of Bangladesh among the medical teachers.

Methods: This cross sectional study was carried out in four medical Institutions situated in Dhaka city and outside Dhaka. Total respondents were 120 teachers working in medical colleges and institute. Opinion of one hundred teachers working in preclinical, para clinical and clinical departments were collected by self administered semi structured questionnaire. Twenty (20) teachers were selected for in depth interview.

Results: Study revealed that thirty eight percent of medical teachers attended in Faculty Development (FD) activity within one year whereas sixty two percent did not participate in any FD activity. Among the attended teachers in FD activity $65.8 \%$ teacher attended by self initiative and $63.2 \%$ were by self funding. All of them mentioned that it was beneficial to them. Twenty percent of medical teachers told in in depth interview that they have no clear cut idea about faculty development activity. Among the respondents, majority (80\%) in indepth interview and $68 \%$ in questionnaires) of the teachers thought that the existing activity in their institution is effective to some extent and few respondents (20\%) in in-depth and 3\% in questionnaires) thought that it is very effective. They also highlighted the areas which should be emphasized for faculty development includes: assessment, professional development, teaching material development etc. Majority of teachers in both the groups in in-depth interview (80\%) and in-structured questionnaires (99\%) opined that a well organized faculty development program is a needed for medical teachers.

Conclusion and recommendation: Existing faculty development activities in different institutions are not very effective. A well-organized faculty development program is a need for medical teachers. A proper policy level guidelines for at periodic training for the teachers can improve faculty development of different institutions.
\end{abstract}

Key words: Faculty development, Medical institution.

1. Dr. Wakil Ahmed, Associate professor, Department of Orthopaedic Surgery Shaheed Taj Uddin Ahmed Medical College and Hospital, Gazipur

2. Dr. Zinat Rehana Shipu, Assistant Professor, Ophthalmology, Shaheed Suhrawardy Medical College and Hospital, Dhaka.

3. Dr. Syed Zakir Hossain, Assistant Professor, Department of Orthopaedic Surgery Dhaka Medical College and Hospital

4. Prof. Dr. Syeda Afroza, Ex-Head Department of Paediatrics, SSMC, Dhaka

5. Prof Dr. Md. Humayun Kabir Talukder, Curriculum Development \& Evaluation Centre for Medical Education (CME), Dhaka

\section{Introduction}

Faculty development is a planned program to improve an individual's knowledge and skills in teaching, educational research and educational administration and to prepare institution and faculty members for various roles. Faculty development deals with training of teachers which leads to

Bangladesh Journal of Medical Education 2020; 11(2); Ahmed et al., publisher and licensee Association for Medical Education. This is an Open Access article which permits unrestricted noncommercial use, provided the original work is properly cited. 
improvement in the quality of teaching and

The World Health Organization recognized the importance of training medical teachers as early as 1965 and suggested creation of three levels of training - Specialist in education, leaders in the field of education and educational practitioners (Singh T.et al, 2008).

University of Illinois and university of Southern California set up centers for medical education in 1969 for the training of regional, national and international teachers. (Srinivas and Adkoli, 2009) In India, first centre for medical education was set up at the Jawaharlal Institute of Post Graduate Medical Education and Research (JIPMER), in Pondcherry in 1976.(Bansal and Supe, 2007).

In Bangladesh, Centre For Medical Education (CME) was established in 1983 at Mohakhali, Dhaka. The centre is trying to create a culture of educational research, generate publications and resources in in Bangladesh. Whereas, primary and secondary school teachers have to undergo training in formal schools or colleges of education to be eligible for appointment, promotion etc. There is no such requirement for appointment of medical teachers. With increasing number of medical colleges and institutions both in government and private sector, there is a marked shortage of teachers. It is critical to maintain educational standards as well as quality of graduating doctors in our country.

There is an urgent need for educational leaders to come forward with strategies to overcome this crisis in medical education. A key to successfully initiating and implementing these is capacity building through faculty development. So, faculty development program is a need of the day learning (Srinivas and Adkoli, 2009).

medical education, provide instructional design, focus on new learning technologies and assessment system, update the curriculum on the basis of needs and conduct some training courses for teachers. CME started a masters course for medical teachers since 2003.

Teaching is a demanding and complex task. Medical education in Bangladesh challenged with shortage of teachers. The teachers are not adequately prepared to handle task in response to the emerging needs (Srinivas and Adkoli, 2009).It is necessary for the present day teacher to be aware of changes that are taking place in medical education. The changes are: Shift from conventional role of teacher, changes in learning styles, innovative curriculum model and changes in assessment philosophy, methods and tools.

There is no formal policy or guidelines for faculty development of medical education for medical teachers. Centre for Medical education (CME) can play a vital role and thus contribute for improvement of medical education throughout the country.

\section{Methodology}

This was a cross sectional study conducted among the teachers/administrators working in selected medical institutions of Dhaka and Chittagong. The period of study was one year. A total of 120 teachers of different Medical colleges and institute expressed their views. Convenience sample technique was adopted. Data was collected by self administered semi structured questionnaire from 100 teachers. In depth interview was conducted with 20 teachers. Ethical issues were taken into consideration. Data was analyzed by using SPSS.

Bangladesh Journal of Medical Education 2020; 11(2); Ahmed et al., publisher and licensee Association for Medical Education. This is an Open Access article which permits unrestricted noncommercial use, provided the original work is properly cited. 


\section{Results}

Table 1 : Distribution of the respondents by their opinion regarding activity $\&$ participation in faculty development event within one year.

\begin{tabular}{|l|c|c|c|c|}
\hline \multirow{2}{*}{} & \multicolumn{2}{|c|}{ Yes } & No \\
\cline { 2 - 5 } & Frequency & Percent & Frequency & Percent \\
\hline $\begin{array}{l}\text { Do you think that there should be any } \\
\text { activity for faculty development }\end{array}$ & 99 & 99 & 1 & 1 \\
\hline $\begin{array}{l}\text { Did you participate in any FD event } \\
\text { within one year }\end{array}$ & 38 & 38 & 62 & 62 \\
\hline
\end{tabular}

Among 100 respondents $99 \%$ thought that there should be activity for faculty development, only $01 \%$ answered that he has no idea about faculty development and 38 percent participated in faculty development event whereas $62 \%$ did not participate in any faculty development event within one year.

Table 2: Distribution of the respondents by their opinion regarding effectiveness of faculty development activities in their institutions. $(n=100)$

\begin{tabular}{|l|c|c|}
\hline \multicolumn{1}{|c|}{ Grade of effectiveness } & Frequency & Percent \\
\hline Highly effective & 3 & 3.0 \\
\hline Effective to some extent & 68 & 68.0 \\
\hline Very little effective & 28 & 28.0 \\
\hline Total & 99 & 99.0 \\
\hline
\end{tabular}

Majority (68\%) of the respondents opined that it was effective to some extent. Only $03 \%$ mentioned that it was very much effective.

Table 3: Distribution of the respondents by their opinion regarding factors affecting the faculty development. $(n=100)$

\begin{tabular}{|l|c|c|}
\hline \multicolumn{1}{|c|}{ Factors } & Frequency & Percent \\
\hline Lack of self interest & 7 & 7.0 \\
\hline Lack of initiative by the dept. & 19 & 19.0 \\
\hline Lack of initiative by the govt. & 48 & 48.0 \\
\hline Lack of guidelines in policy level & 81 & 81.0 \\
\hline Over load of duties of teachers & 5 & 5.0 \\
\hline Lack of interest of senior teachers & 13 & 13.0 \\
\hline National politics & 29 & 29.0 \\
\hline Teachers politics & 54 & 54.0 \\
\hline
\end{tabular}

Bangladesh Journal of Medical Education 2020; 11(2); Ahmed et al., publisher and licensee Association for Medical Education. This is an Open Access article which permits unrestricted noncommercial use, provided the original work is properly cited. 
Original Article

Regarding factors affecting faculty development $81 \%$ respondents thought that lack of guide lines in policy level might affect the faculty development. Other factors like teachers politics was mentioned by $54 \%$ teachers, lack of initiative by the govt. by $48 \%$, national politics by $29 \%$ and then lack of initiative by the dept.(19\%) might affect the faculty development events

Table 4: Distribution of the respondents by their ideas regarding area of improvement through faculty development programme. $(n=100)$

\begin{tabular}{|l|c|c|}
\hline $\begin{array}{c}\text { Areas for improvement through } \\
\text { FD }\end{array}$ & Frequency & Percent \\
\hline Assessment & 61 & 61.0 \\
\hline Teaching material development & 6 & 6.0 \\
\hline Curriculum development & 4 & 4.0 \\
\hline Professional development & 28 & 28.0 \\
\hline Research & 1 & 1.0 \\
\hline Total & 100 & 100.0 \\
\hline
\end{tabular}

Among 100 respondents $61 \%$ opined that assessment may be improved through FD programme and $28 \%$ mentioned the professional development.

Table 5 : Distribution of the respondents by their suggestions regarding further improvement of the activity ( $n=100)$

\begin{tabular}{|l|c|c|}
\hline \multicolumn{1}{|c|}{$\begin{array}{c}\text { Suggestions for further } \\
\text { improvement of the activity }\end{array}$} & Frequency & Percent \\
\hline Proper guidelines at policy level & 61 & 61.0 \\
\hline Periodic training & 78 & 78.0 \\
\hline CME/CPD activities & 47 & 47.0 \\
\hline
\end{tabular}

For further improvement of faculty development majority of respondents (78\%) gave suggestions for periodic training, $61 \%$ on proper guidelines at policy level, $47 \%$ on CME/ CPD activities.

\section{Discussion}

This study was carried out to explore the "Current status of faculty development events in different medical institutions of Bangladesh."

In this study, majority of the respondent teachers felt the need of faculty development program for the medical teachers in Bangladesh. A conference entitled "A 2020 vision of faculty development across the medical education continuum" arranged by Association of American Medical Colleges had similar recommendation for a well organized faculty training program (Searle et al, 2011).

This study revealed that majority (62\%) of the respondent did not attended any faculty development activity within one year and all the respondent who attended (38\%) was for a short duration (1-3 days). Report on teaching scholars program at West Virginia University (Fidler DC et al, 2007) has similarity with the present study that they developed a one week program Bangladesh Journal of Medical Education 2020; 11(2); Ahmed et al., publisher and licensee Association for Medical Education. This is an Open Access article which permits unrestricted noncommercial use, provided the original work is properly cited. 
consisting of full- day session for faculty development in 2005. Area covered in that programme were instructural material development like power point, handouts etc.

In this study, all the respondents stated that the events they attended were beneficial to them. Report of Fidler DC et al (2007), has similarity with the present study. After reviewing the faculty development programs in different Universities like Harvard, University of Michigan, John Hopkins etc. Report revealed that the program had positive outcome mentioning different beneficial aspects.

Among 100 respondents in present study $61 \%$ gave emphasis on assessment, $28 \%$ on professional development, $6 \%$ on teaching material development, $4 \%$ on curriculum development, and $01 \%$ on research for development of a medical teacher. This finding is comparable with the findings of Kabakci and Odabasi (2008) in Turkey on preference of research assistants on faculty development areas. They preferred the professional development in the first place, instructional material development in second place, personal development in third and institutional development in fourth place.

According to the respondents, means those exists in their institutions for faculty development of medical teachers are ACR $69 \%$, supervision by departmental chair $19 \%$, regular FD program 5\%, supervision by principle and CME activity $3 \%$ respectively. Regarding effectiveness of the faculty development activity $68 \%$ respondents think that the effectiveness is to some extent, $28 \%$ very little and $3 \%$ very much effective. Sing et al, (2008) reported in a country paper of India that there is no formal training program existed for faculty development and it is clear from their report that the faculty development activity is not much effective in India.

According to the respondents, the ways that can be adopted for development of competencies of medical teachers are: Training (100\%), CME/CPD activities $(80 \%)$, better promotion and posting for efficient teachers $(40 \%)$, financial support $(30 \%)$, adequate measures for inefficient teachers (20\%) and exchange program among different institutions(10\%). This finding has some similarity with the findings of Jarvis (1992a) and of Mu (1997) that organizing faculty development programs for faculty members in the form of workshop and seminars will be the most appropriate.

Regarding barriers affecting the faculty development activity $81 \%$ respondent think of lack of proper guide line in policy level, $54 \%$ due to teachers politics, $48 \%$ due to lack of initiative by the government. Present study can be compared with Srinivas and Adkoli's (2009) report, Faculty development is constrained by lack of commitment at various levelsCentral and State government, regulatory bodies, college management and teachers.

In this study, regarding further improvement of faculty development activities in Bangladesh $78 \%$ respondent gave suggestion for periodic training, $61 \%$ for proper guideline at policy level and 47\% for CME and CPD activities. Srinivas and Adkoli (2009), recommended in a review article having similarity with present study and recommended periodic training should be an essential requirement for career development \& promotion.

\section{Conclusion and recommendation}

From the present study it can be concluded that, faculty development programme is a

Bangladesh Journal of Medical Education 2020; 11(2); Ahmed et al., publisher and licensee Association for Medical Education. This is an Open Access article which permits unrestricted noncommercial use, provided the original work is properly cited. 
need for medical education. Existing activity for faculty development like regular $\mathrm{CME}$ or $\mathrm{CPD}$, periodic training for teachers or regular supervision by departmental chair in different medical institutions are not very effective. Teachers' training has no alternative for their development. Innovative teachers should be rewarded with fellowship for

\section{References}

Bansal P \& Supe AN (2007). Training of medical teachers in India: Need for change. Indian Journal of Medical Science.61: 478-484.

Behar-Horenstein LS, Schneider-Mitchell G, Graff R (2009). Promoting the teaching of critical thinking skills through faculty development. Journal of Dental Education.73:665-675.

Burdick, WP, Morahan PS \& Norcini JJ (2007). Capacity building in medical education and health outcomes in developing countries. Education for health [online],65. Available at http://www.educationforhealth.net (Accessed : 12 April 2012)

"Continuing Medical Education" (Retrieved 14 February 2012). CME Schedule (Online). Available at http://www.cmeschedule.com/aboutcontinuing-medical-education-cme/ (Accessed : 20 October 2012).

Fidler DC, Khakoo R, Miller LA (2007). Teaching Scholars programs: Faculty development for educators in the health professions. Academic Psychiatry.31: 472-478.

Hess GF (2006) Improving teaching and learning in law school: Faculty development research, principles and programs. Widener L Rev. 12 : 443-471 training, promotion or better posting etc. Despite different obstacles, a well organized faculty development programme should be a continuous process for the academic development of the medical teachers. Before all, there should be a clear cut guide line for faculty development at policy level, as well as regular CME/ CPD activities.

Jarvis DK (1992a). Junior Faculty development: A Handbook. Second edition. New York: The Modern Language Association of America.

Kabakci, Odabasi FH (2004). Evaluation of an online faculty development course from the point of view of participants, E-learn 2004 World conference on Elearning in corporate, Government, Healthcare and Higher education., The proceeding book of E- learn 2004 Conference, Washington, DC/ ABD.

Kabakci, Odabasi FH (2008). The organization of the faculty development program for research assistants: The case of education faculties in Turkey. TOJET: 7: 56-63.

Searle N S, George E, Thibault, Greenberg (2011). Faculty development of medical educators : Current barriers and future directions. Academic medicine, 86: 405-406.

Singh T, Bansal P, Sharma M (2008). A need and necessity for faculty development: the role of medical education unit in the Indian context. South East Asian Journal of Medical Education. 2: 2-6.

Srinivas D.K., Adkoli B.V (2009). Faculty development in medical education in India: The need of the day. Al Ameen J Med Sci. 2: 6-13.

Van der Merwe, M; Van der Merwe, Alta; (2008), Online Continuing

Bangladesh Journal of Medical Education 2020; 11(2); Ahmed et al., publisher and licensee Association for Medical Education. This is an Open Access article which permits unrestricted noncommercial use, provided the original work is properly cited. 
Original Article

$\begin{array}{ll}\text { ProfessionalDevelopment: tensions } & \text { Journal (42). Available at } \\ \text { impacting on the reflective use of a } & \text { en.wikipedia.org/wiki/Continuing_Prof } \\ \text { mathematics-friendly } & \text { essional_Development (Accessed : } 20 \\ \text { environment, South African Computer } & \text { October 2012). }\end{array}$

Bangladesh Journal of Medical Education 2020; 11(2); Ahmed et al., publisher and licensee Association for Medical Education. This is an Open Access article which permits unrestricted noncommercial use, provided the original work is properly cited. 